San Jose State University

SJSU ScholarWorks

Master's Theses

Master's Theses and Graduate Research

Fall 2011

\title{
A Survey of Female Characters as Flâneuses and Their Interactions with Modernity in Early Modern British Literature
}

Thao Thi Nguyen

San Jose State University

Follow this and additional works at: https://scholarworks.sjsu.edu/etd_theses

\section{Recommended Citation}

Nguyen, Thao Thi, "A Survey of Female Characters as Flâneuses and Their Interactions with Modernity in Early Modern British Literature" (2011). Master's Theses. 4106.

DOI: https://doi.org/10.31979/etd.epkg-7gfn

https://scholarworks.sjsu.edu/etd_theses/4106

This Thesis is brought to you for free and open access by the Master's Theses and Graduate Research at SJSU ScholarWorks. It has been accepted for inclusion in Master's Theses by an authorized administrator of SJSU ScholarWorks. For more information, please contact scholarworks@sjsu.edu. 


\title{
A SURVEY OF FEMALE CHARACTERS AS FLÂNEUSES AND THEIR INTERACTIONS WITH MODERNITY IN EARLY MODERN BRITISH LITERATURE
}

\author{
A Thesis \\ Presented to \\ The Faculty of the Department of English and Comparative Literature \\ San Jose State University \\ In Partial Fulfillment \\ of the Requirements for the Degree \\ Master of Arts \\ by \\ Thao Nguyen \\ December 2011
}


(C) 2011

Thao Nguyen

\section{ALL RIGHTS RESERVED}


A SURVEY OF FEMALE CHARACTERS AS FLÂNEUSES AND THEIR INTERACTIONS WITH MODERNITY IN EARLY MODERN BRITISH

LITERATURE

\author{
by \\ Thao Nguyen \\ APPROVED FOR THE DEPARTMENT OF ENGLISH AND COMPARATIVE \\ LITERATURE \\ SAN JOSE STATE UNIVERSITY
}

December 2011

$\begin{array}{ll}\text { Dr. Angela Noelle Brada-Williams } & \text { Department of English and Comparative Literature } \\ \text { Dr. Andrew Fleck } & \text { Department of English and Comparative Literature } \\ \text { Dr. Adrienne Eastwood } & \text { Department of English and Comparative Literature }\end{array}$ 


\title{
ABSTRACT
}

\section{A SURVEY OF FEMALE CHARACTERS AS FLÂNEUSES AND THEIR INTERACTIONS WITH MODERNITY IN EARLY MODERN BRITISH LITERATURE}

\author{
by Thao Nguyen
}

This thesis argues that the flâneuse is present in literature well before the late nineteenth century. Similar to Charles Baudelaire's flâneur figure, the flâneuse herself is an observer of modernity. Through her interactions with the crowd, the flâneuse is able to read the urban landscape. Chapter One focuses on defining the historical context of when the term flâneur appears in critical discourse. Chapter Two introduces the first example of a flâneuse: the narrator of Isabella Whitney's poem "Will and Testament." It focuses on how the narrator offers a reading of London in flux, its attractions as well as its growing problems. Chapter Three presents flâneuses of the seventeenth century: Moll from The Roaring Girl and Hellena from The Rover. These two texts introduce the crowd and present flâneuses who interact with the crowd. They also present the power and dangers of using costumes to enter into public spaces and for walking on the streets. In Chapter Four, we enter the eighteenth century, and through Moll Flanders and Evelina, we explore how the ideology of the separate spheres dictated women's roles and where women could frequent. Even more important to this study is the fact that this ideology ultimately limited women's roles as flâneuses for much of the eighteenth and nineteenth centuries. 


\section{ACKNOWLEDGEMENTS}

This thesis is dedicated to my father, who believed in me and supported my academic interests. Yet its completion would not have been possible without the continued support of the following people:

* My family — for being a strong, loving, and encouraging center in my life.

* Professor Angela Noelle Brada-Williams - for reading every single draft that came her way. For that, I will always remain grateful.

* Professors Adrienne Eastwood and Professor Andrew Fleck

* Yelena Severina 


\section{TABLE OF CONTENTS}

Introduction 1

Chapter One: Introducing the Flâneur 4

Chapter Two: Isabella Whitney_The First Flâneuse 22

Chapter Three: Costumes and the Dangers of Walking in

The Roaring Girl and The Rover 29

Chapter Four: Thievery and Public Gardens in Moll Flanders and Evelina 44

$\begin{array}{ll}\text { Conclusion } & 66\end{array}$

$\begin{array}{ll}\text { Works Cited } & 69\end{array}$ 


\section{Introduction}

The crowd is his element, as the air is that of birds and water of fishes. His passion and his profession are to become one flesh with the crowd. For the perfect flâneur, for the passionate spectator, it is an immense joy to set up house in the heart of the multitude, amid the ebb and flow of movement, in the midst of the fugitive and infinite. (Baudelaire, "Painter" 9)

This description, from the 1863 publication of "The Painter of Modern Life" by nineteenth-century French critic and poet Charles Baudelaire, presents a figure reveling in a sea of strange faces and welcoming the flux of things. This figure is traditionally a man of leisure and with the financial means to wander the city streets to observe the many shapes of modernity. Scholarly research on this figure being female, a flâneuse, limited her presence to the late nineteenth century with its overt commercialization of cities like Paris and London. The popularization of shopping as a pastime for women means that their presence on the streets became more prominent. Yet women's presence in the urban landscape goes back further.

This thesis argues that the flâneuse is present in literature well before the late nineteenth century. Similar to Baudelaire's figure, the flâneuse herself is an observer of modernity. She interacts with the crowd, and through encounters on the streets, the flâneuse creates a reading of the urban landscape-one that presents the city in its rawest forms. While the flâneur of Baudelaire's creation demands to be incognito, wanting "to 
be the centre of the world and yet to remain hidden from the world," (Baudelaire, "Painter" 9) the flâneuse is not granted this freedom. Women cannot walk the street aimlessly, and they cannot remain inconspicuous to merely observe the crowd. In order to be unobserved, the flâneuse employs costumes. To argue that the flâneuse as an observer of modernity exists (fully developed or not) well before the nineteenth century, I begin by defining modernity and what it means to be an observer of modernity. Although a flâneuse can be an observer, her mere presence on the streets makes it difficult for her to be a detached observer. Though the flâneuse lacks the power to remain incognito, what distinguishes the flâneuse from her male counterpart is that she eventually steps away from her role as just an observer. The larger purpose is to give these female strollers a critical voice and to redefine Baudelaire's image of the mute, passive female walker. The development of the flâneuse focuses on women becoming more vocal of their criticisms and fearless in their interactions with crowds in the urban landscape.

Chapter One focuses on first defining the historical context of when the term flâneur appears in critical discourse. Drawing on Dana Brand's argument, I present the case for an early modern flâneur. In continuation, I present popular arguments concerning the flâneuse and make the assertion that there is the possibility of one showing up in early modern literature. The chapter ends with a definition of modernity, the idea of looking at public spaces, in particular city streets, shopping scenes, and public gardens, to define the flâneuse. In Chapter Two, I introduce my first example of a flâneuse: the narrator of Isabella Whitney's poem "Will and Testament." I focus on how the narrator offers a reading of London in flux, its attractions as well as its growing 
problems. Whitney's narrator, somewhat autobiographically created, is an example of a flâneuse because of her power of observation. In continuation, Chapter Three presents flâneuses of the seventeenth century: Moll from The Roaring Girl and Hellena from The Rover. These two texts introduce the crowd and present flâneuses who interact with the crowd. They also present the power and dangers of using costumes to enter into public spaces or for walking the streets. In Chapter Four, we enter the eighteenth century, and in both Moll Flanders and Evelina, we see elements of the crowd and how though costumes grant entrance to certain places, they do not guarantee the flâneuse a safe exploration. Through these two texts, I want to explore how the ideology of the separate spheres dictated women's roles in the eighteenth century and where women could frequent. Even more important to this study is the fact that this ideology ultimately limited women's roles as flâneuses for much of the eighteenth and nineteenth centuries. 


\section{Chapter One: Introducing the Flâneur}

Any study of the flâneur needs to begin with Baudelaire and with nineteenth century Paris, for without these two factors, the flâneur that scholars have searched for and written about would have been drastically different. The year was 1889 , the year of the great World Exhibition in Paris. In preparation for the World Exhibition, the city had undergone a complete transformation. The exhibits occupied an area that included the Champs de Mars, the Trocadero, the Quai d'Orsay, the Invalides Esplanade and part of the Seine. The Eiffel Tower, completed that same year, served as the entrance arch to the fair. It was an exhibition that showcased the progress the world has made. Innovations in technology, science, and cultural studies were celebrated. Forty-four cultures were represented; yet instead of showcasing authenticity, these exhibits fabricated the exoticness of other cultures. T.J. Clark, a twentieth-century art historian, writes: "No one exactly believed in the exhibition, at least not in its claim to represent the world" (61). The people attended these exhibitions because they were attracted to the crowd, to what the exhibition as a whole represented: change. Clark further asserts that since the 1830 s, Parisians understood that Paris was on the brink of change, and they were trying to communicate these changes, turning them into something visible. Clark calls this effort the "wish to visualize" a process of change and to have the modern city become "an image" (66). Baron Haussman's efforts, Clark argues, were to give the encroaching modernity a shape, to turn Paris into a spectacle, a visceral experience that people could 
understand (Clark 66). What these artists tried to communicate was the ever prominent presence of capitalism in everyday life:

What they wished to describe, in a word, was capitalism coming to determine the main motions of social life - altering the ways in which men and women worked, bought, sold, set up house, and arranged their day. Capitalism was assuredly visible from time to time, in a street of new factories or theatricals of the Bourse; but it was only in the form of the city that it appeared as what it was, a shaping spirit, a force remaking things with ineluctable logic. (Clark 69)

Inspired by these efforts to make modernity understandable and visible, Charles Baudelaire introduced the image of the flâneur - a figure who observes and tries to capture the many shapes of modernity. Baudelaire fully articulated and named this figure in his 1863 publication of "The Painter of Modern Life." In this essay, Baudelaire describes a figure that roams the streets searching for modernity. Baudelaire calls him the flâneur, and modernity, he writes, is "the ephemeral, the fugitive, the contingent, the half of art whose other half is the eternal and the immutable" ("Painter" 13). Baudelaire equates modernity with what is constantly changing. Modernity is a "transitory, fugitive element" whose metamorphoses are so rapid that one cannot attempt to "despise or dispense with it" (Baudelaire, "Painter" 13). The flâneur attempts to distinguish the eternal in this sea of flux: "He makes it his business to extract from fashion whatever element it may contain of poetry within history, to distill the eternal from the transitory" (Baudelaire, "Painter" 12). Modernity is short-lived, but the flâneur is an artist "who observes and seeks the meaning of his modernity" (Tester 17). He then captures the 
fleeting moments in art, making the ephemeral eternal. The crowded streets become the locale where he carries out his most important endeavor - that of observing. The crowd is a necessity that allows him to adopt the detached attitude that will become his signature mark.

To be away from home and yet to feel oneself everywhere at home; to see the world, to be at the centre of the world, and yet to remain hidden from the world-such are a few of the slightest pleasures of those independent, passionate, impartial natures which the tongue can but clumsily define. The spectator is a prince who everywhere rejoices in his incognito. (Baudelaire, "Painter" 9) Baudelaire's flâneur figure has some marked characteristics: a familiarity with and an attraction to the crowd paired with a desire for anonymity and detachment from the crowd. It is this hybrid paradoxical nature of the flâneur that makes him the perfect observer of modernity.

Research concerning the flâneur has mostly traced him back to the nineteenth century when writers began to depict modern cities in their writings. However, Dana Brand proposes that the development of the flâneur began in the sixteenth century. Brand's premise states that the beginning sketches for the flâneur began with the "culture of the spectacle" (Brand 14) in sixteenth century London when the city became not only a political center but also Europe's main commercial center. Growth in various commercial ventures turned London into a metropolis with a diverse population, and thus the consumer society necessary for the development of a flâneur came into existence. The physical representation of London's consumer society was the Royal Exchange. 
Constructed in 1568, the Exchange became the first of many public meeting spaces where people meet and observe one another. Brand writes: "Wealthy Londoners, dressed in the latest fashions, could observe each other, gossip, exchange news, and purchase goods designed to demonstrate their wealth" (15). Similar to the Royal Exchange, the eighteenth century pleasure gardens of London visited by Frances Burney's heroine Evelina would later adopt a similar purpose of being a place where the general public gathered to display themselves and observe the masses.

Though London as a great metropolis had been mentioned before in literary texts, Brand believes that it was not until the late sixteenth century and early seventeenth century that literary texts devoted solely to describing the city began to be in circulation. He categorizes these early texts on the city as "urban genres" and believes that they allowed writers to view London as a conglomeration of commercial and cultural changes. Writers of these genres attempted to record the "fugitive" nature of a changing city in constant flux. These "urban genres" give the first defining characteristic of the flâneur and his world. There is a sense that the spectacle watched (e.g., the city, the crowd) is not static and a complete entity but "rapidly changing and randomly encountered" (Brand 19). The first example of these urban genres that Brand cites is John Stow's Survey of London. Published in 1597, Stow's book presented the city as an independent being with values and ethos separate from the church and crown (Brand 17). Complemented by Visscher's panoramic engraving of Elizabethan London, Stow's Survey became one of many books in early seventeenth century that offer panoramic descriptions of the city. Encyclopedic in nature, these books compartmentalized the city into separate spaces so 
that readers would get a more organized view of London (Brand 17). Brand argues that these early guides anticipated the flâneur's consciousness of dividing the city into individual spaces, turning the city into "something that can be read and grasped in its entirety" (17). Following Stow's book were the "coney-catching books." These were also encyclopedic in nature but they captured not well-known activities or buildings in the city but the various ways one can be deceived and cheated by the class of beggars, thieves, prostitutes, and con-men. However, both the "urban genres" books like Stow's and the "coney catching books" attempted to capture the city at a specific period in time, thus creating the illusion that the city is static when in fact it is constantly changing.

What came after the "coney-catching" books was the Theophrastian character book. These books combined character sketches modeled on classical Greek antecedents with the popular literary genres at the time. Brand believes that these sketches or types allowed readers to formulate the idea that if they encounter a stranger on the street who is dressed in a certain way, visits a certain place, or has some recognizable facial features, then the readers can expect this stranger to act a certain way, thus fitting a certain character mold (22). This idea of a walker who is able to recognize the character and history of a stranger on the streets based on a random and brief encounter is the second defining characteristic of a flâneur. The flâneur finds comfort in his anonymity. In fact, the Theophrastian character writer's ability to view and then present what he saw in an “empirical and inductive manner" is in some way a precursor to the flâneur's ability to be a detached and curious observer of the crowd (Brand 25). Furthermore, since there was no portrait of the writer of these sketches, his invisibility begged readers to think about 
him. The Theophrastian character book however was also problematic; it tried to present an orderly world where social categories seem fixed.

Brand further traces the development of the flâneur by looking at periodical publications and argues that these texts came closer to capturing the flux. He argues that Tom Brown's London Amusements (1700), Ned Ward's London Spy (1698-1700), and the English Lucian (1698) developed patterns that would later appear in urban pieces like Joseph Addison's \& Richard Steele's The Tatler (1709-1711) and The Spectator (17111712). These texts presented the city in monthly installments through the eyes of a detached observer. Unlike the character books or the survey books of Stow's which attempted to present the city as "legible, complete, and static," these periodicals focused on the ephemerality and contemporariness of its content (Brand 27). Each installment prided itself on detailing what had changed since the last installment. In this sense, these periodicals came closer to capturing the flux that was inherent with modernity, presenting the experience of modernity and reality "as a perpetually new and discontinuous spectacle that can be consumed by a spectator unable to influence what he or she observes" (Brand 27). Brand argues that the London Spy and the English Lucian presented a carnivalesque view of the world. There are fluidity of identities, crossdressing, and confusion concerning the gender of your bedmates (Brand 29). Another characteristic that makes these texts carnivalesque is the way in which these writers use these elements to question power relations. The public spaces that were once part of the respectable political and economic worlds are portrayed as places where "lustful and illicit activities" happen (Brand 29). Respectability has gone out the window, and the 
Royal Exchange becomes a place where the exchange of male and female as commodities happen (Brand 29). Yet for Brand, these pre-Addison \& Steele texts, though carnivalesque in essence, came closest to capturing modernity. Instead of presenting an orderly world, the writers presented the city in a way that would welcome disorientation and sensory overload. The urban spectator neither interpreted nor judged the content he presented to his readers.

From these predecessors, the flâneur developed into a figure without any obligations - social, familial, or economic. He became a man who can describe the vices in lengthy details yet can still create the illusion that the readers are "safe." A decade later, Addison and Steele added to the make-up of the flâneur a degree of power. The flâneur, in these two men's writings, is able "to impose order, continuity, and coherence in the act of watching what appears to be chaotic" (Brand 33). Steele and Addison introduced a spectator with the ability to watch the chaos of the modern city yet in the midst of chaos has the power to impose "order, coherence, and continuity" (Brand 29). The city does not have to be presented as fixed or frozen - there is randomness for the spectator to encounter-yet the spectator is in control, processing what he sees. What gives the flâneur power to do this is his social privilege. Steele and Addison made the Spectator a bachelor with a moderate income, detached from any obligations (Brand 33). Such a bachelor lacks the obligations of his fellow citizens and can spend his time engaged in interpreting the scenes surrounding him. By the time The Spectator was in publication, the development of the flâneur, as Baudelaire paints him in "The Painter of Modern Life," was already in completion. 
The figure of the flâneur tends to be imagined as a man, able to exploit his masculine independence to venture into these crowded public spaced. In fact, critics doubt the existence of the flâneuse before the twentieth century. However, as we shall see, there are women wanderers in urban landscapes from the same time as the early modern flâneurs. Brand limits the argument when he says:

The absence of flâneries written by women is undoubtedly significant, and presumably reflects a sense in the culture that there is something inappropriate about women enjoying the degree of access to the consciousness and character of others that the flâneur traditionally claims for himself, or expressing the unselfconscious love of spectacle and luxury that he traditionally expresses. (Brand 200)

The flâneur requires a freedom from "social attachments and responsibilities" (Brand 199). He has to remain inaccessible and invisible in the crowd; he needs to be able "to explore, stare at, and observe everything within the city" (Brand 199). For Brand, women who wanted to become the female counterpart of this figure simply did not meet these prerequisites. The many roles that women could adopt in the safety and socially sanctified domestic realm were that of a wife, daughter, and mother. Outside, on the streets, those of the working class became less respectable and more commodified into an object for sale. Those of the middle class were instead romanticized, adopting a muselike quality like the women that graced Baudelaire's works.

In Baudelaire's Fleurs de Mal (Flowers of Evil), his collection of poetry first published in 1857, the poem "A Une Passante" (To a Passer-by) best exemplifies 
Baudelaire's view of a female walker. The poem places women's purpose on the streets as one of inspiration. The narrator encounters an unknown woman on the "deafening" streets. A glance between the narrator and this woman is described as a flash of lightning, evoking a sense of renewal, a spiritual awakening in the poet. Yet there is also danger in such a meeting on the streets: "From her eyes, pale sky where tempests germinate, / the sweetness that enthralls and the pleasure that kills" (Baudelaire, "Passerby" 311). This powerful female figure is not only dangerous but she is also "fleeting." This chance encounter is emblematic of the modern experience. Here is a representation of modernity and its fleetingness; the interactions of strangers in the crowded streets where identities and purpose are assumed, yet nothing is permanent. The encounter between the poet and this woman leaves as quickly as it came. Yet while it lasted, it offered the poet energy. The poet turns the encounter into a work of art; he turns her coyness and omniscient qualities into elements that propel him to create art. She becomes his muse.

How this muse-like female walker gains access to this public space is because of her status as a widow. Baudelaire describes as "tall, slender, in heavy mourning, majestic grief" ("Passer-by" 311). Had this figure been portrayed as a young woman, her purpose on the streets would have been misconstrued to be something more promiscuous. A young woman cannot walk the streets un-chaperoned. Six years later, with the publication of "The Painter of Modern Life," Baudelaire once again addresses the question of women being flâneuses. In the section titled "Women," Baudelaire explains how women are a creature whose only role is to serve as the muse for men: 
The being towards whom, or on behalf of whom, all their efforts are directed; that being as terrible and incommunicable as the Deity ... incomprehensible because it has nothing to communicate ... that being in whom Joseph de Maistre saw a graceful animal whose beauty enlivened and made easier the serious game of politics; for whom, and through whom, fortunes are made and unmade; for whom, but above all through whom (emphasis added by author) artists and poets create their most exquisite jewels; the source of the most exhausting pleasures and their most productive pains. ("Painter" 30)

The language of "through whom" indicates woman's submissiveness - that she not only allows men to assign monetary values to her, but also to use her for their games and arts. Seen under this light, it becomes matter-of-fact that women cannot venture past their domestic space. Such freedom would not match Baudelaire's descriptions of the accommodating, submissive muse. Yet Baudelaire's descriptions, as well as Brand's argument against the existence of the flâneuse, are deeply rooted in the ideology of separate spheres governing women of the middle class. Women were indeed restricted to the home because of the sexual divisions during the nineteenth century. Critics studying the flâneuse have argued that the lack of freedom to roam the streets, to enter public areas unless accompanied by men, and to participate in things related to the public sphere made the existence of the flâneuse almost impossible. The idea of a solitary woman who wanders the streets without any purpose only brings social stigma. Women had no accepted place outside the domestic realm. And while the category of working women 
existed, a woman who had such status meant she could no longer lay claim to her status as a woman (Pollock 68).

Critics studying the figure of the flâneuse in literature have turned to Janet Wolff's study on women and modernity. Wolff offers three reasons as to why women were nearly invisible or obscurely portrayed in the literature of modernity. The first reason has to do with the nature of the field of sociology. As a new field during the nineteenth century, it was dominated by men and it focused only on the public realms: work, politics, and the market place (Wolff 44). Although women worked in factories, mills, schools, and offices, the traditional sociological texts did not record their experiences and so these women and their experiences were edited out of the contemporary accounts of the time. The second reason has to do with the "partial conception of modernity" (Wolff 44). The literature of "modernity" of the nineteenth century mainly focused on the "public" sphere. As a result of this, Wolff writes: "what is missing in this literature is any account of life outside the public realm, of the experience of 'the modern' in its private manifestations, and also of the very different nature of the experience of those women who did appear in the public arena" (47). Women showed up in literature as an addendum or an extension to men's existing presence. If she showed up in the public sphere, it was through, what Wolff describes as "illegitimate or eccentric routes" (45) that required her to adopt the roles of whore, widow, or murder victim. In conjunction with this skewed perception of modernity, presented only through the male's point of view, was the fact that women's lives were markedly varied. The doctrine of the separation of spheres made it seem like women only belonged to the domestic realm, but 
Wolff argues that the reality was that a woman's situation varied depending on her class, geographical location, or industry (Wolff 45). The rise of the department store in the $1850 \mathrm{~s}$ and $1860 \mathrm{~s}$ allowed this space to become a public area for women to frequent, and they took part in the consumer industry as shoppers. Yet this is where Wolff differs from later critics. The literature of modernity for her demands the writers to account for the "fleeting, anonymous encounter and purposeless strolling" (Wolff 46). Wolff ends the chapter with the statement: "there is no question of inventing the flâneuse: the essential point is that such a character was rendered impossible by the sexual divisions of the nineteenth century" (47). Writings about the flâneuse and by the flâneuse simply were non-existent, in Wolff's influential view.

While some contend that a flâneuse cannot exist before the nineteenth century because of the sexual divisions during the period, there are critics who argue that nineteenth century London, like its neighbor Paris, was the ideal environment that might have fostered her presence due to the growing commercial industry. While the doctrine of the separation of spheres was still the dominating factor, women made use of the public spaces opened up for them (e.g., the department stores, theaters, parks) for their own observations. Anne Friedberg argues for the shopper as an example of a flâneuse in the making. She associates the presence of the flâneuse with the increasing popularity of the department store in mid-nineteenth century and argues that as the department store took the place of the arcades, women gained more freedom. They had purchasing power, could go shopping alone, and overall had the freedom to roam the streets. Friedberg writes: "the female flâneur was not possible until a woman could wander the city on her 
own, a freedom linked to the privilege of shopping alone" (421). Yet Friedberg's argument presents the department stores as an enclosed space for women. The department store became "a safe haven for unchaperoned women," "constructed fantasy worlds for itinerant lookers," and "offered a protected site for the empowered gaze of the flâneuse" (Friedberg 421). Friedberg's vocabulary shows how the space for the flâneuse to practice her power of observation is no more than a constructed space. Lacking the flux and dangers associated with modernity, there is no power in her gaze and observations. In contrast, Priscilla Parkhurst Ferguson criticizes the act of shopping, labeling the activity as distracting. It strips from the flâneuse the one quality that is imminent to her presence on the streets: concentration. A flâneuse is supposed to gaze on everything in the cityscape with indifference; shopping makes the flâneuse desirous of materials around her. Ferguson writes: "The intense engagement of the shopper in the urban scene, the integration into the market and the consequent inability to maintain the requisite distance, preclude the neutrality and objectivity that the flâneur cultivates so assiduously" (27). The flâneuse ends up losing her ability to objectively present the cityscapes.

Griselda Pollock, though her scholarship is mainly in the field of art history, offers an innovative way of looking at the works produced by women during the nineteenth century. Pollock's essay looks at two female impressionist artists: Mary Cassatt and Berthe Morisot. Pollock questions why modernism, particularly in her field of study, deals so much with masculine sexuality and women's bodies in both public and private places (e.g., the brothels, the bars, the bedrooms). The answer she comes up with 
is that what the modernist art historians celebrated was a strictly male's perspective of what modernity was (Pollock 82). In many of the canonical works produced in the nineteenth century, there was an emphasis on equating women's sexuality as a form of commercial exchange. The territories of women's bodies were for male artists to claim their modernity and to exhibit their experiments with techniques. Arguing that sexuality, modernity, and modernism are all concepts organized around sexual differences, Pollock sets out to see how sexual differences show up in paintings by the two female artists Cassatt and Morisot. Using space as the matrix to evaluate their works, she looks at space in terms of locations, space in terms of a technique of ordering subjects in the paintings, and space in terms of the social environment from which the paintings were made. Pollock concludes that modernity and modernism are "sexualized structures" in that they are defined mainly by men (102). Women who were producers of art had to negotiate modernity and the spaces of femininity by developing alternative models (Pollock 102).

In relations to this study, Pollock's idea of looking at space as a matrix in which female artists represent their experiences with modernity serves as the starting focus to look at these early texts depicting women's experiences with the city. While the separation of spheres explains to some extent women's status and roles in the nineteenth century, this frame of outlook does not explain women's interactions with the city in the centuries long before this ideology was cemented. In speaking of London in the late sixteenth century to the end of the eighteenth century, the ideology of the separation of spheres was still in development. For one thing, the phenomenon of the separation of 
spheres was class-based and not gender-based. In earlier periods of British history, gender roles were not strictly defined the way they were during the nineteenth century. In order to trace the birth of the flâneuse, we have to look beyond this nineteenth century cultural ideology.

Stephen Toulmin begins his study of modernity by stating that dating modernity will only bring confusion since its beginning means different things to different people; he writes:

Some people date the origin of modernity to the year 1436, with Gutenberg's adoption of moveable type; some to A.D. 1520, and Luther's rebellion against Church authority; others to 1648 , and the end of the Thirty Years' War; others to the American or French Revolution of 1776 or 1789; while modern times start for a few only in 1895, with Freud's Interpretation of Dreams and the rise of 'modernism' in the fine arts and literature. (5)

From such an introduction, it would seem as if Toulmin does not believe in a specific beginning for modernity and would likely favor this conglomeration of different beginnings. On the contrary, his study presents a specific date--two to be more exact. The general consensus concerning the beginning of the modern age is linked to the birth of the "rational" (Toulmin 13). This marks the beginning of modernity to be somewhere between 1600 and 1650s with the publications of Galileo's works and Descartes' Meditations and Discourse on Method (1630s) revolutionizing the way people view the universe and humanity. Yet, Toulmin does not agree that this is the only date for the 
beginning of modernity. He proposes that there is an earlier birth date. The first phase of modernity occurred during the late Renaissance period with writers such as Shakespeare and Montaigne. In the literary traditions of this time, these writers planted seeds of modern thoughts that would later be joined with the scientific and philosophical revolution of the early seventeenth century to form what has been called the birth of the rational (Toulmin 23).

Miles Ogborn, expanding on Toulmin's premise, argues that there are different modernities for different places. Taking the term "spaces of modernity" (coined by Griselda Pollock), he analyzes what he considers to be spaces of modernity in nineteenthcentury London. In his introductory chapter, he asserts that modernity does not belong to a specific space or time. There is no single definition or single temporality that can be considered "modern," nor is modernity merely referring to the degree of transformation by capitalism (Ogborn 5). His study concentrates on London spaces, bounded or imaginary, consisting of the "prostitutes' penitentiary, the newly paved streets, the pleasure garden, and the bureaucratic network, and the Universal Register Office's web of commercial transactions" (Ogborn 27). He argues that by studying these public spaces, scholars are paying attention to the ways in which they were produced, whether by important "material changes to practices, institutions, or experiences" (Ogborn 20). While there have been disagreements about when "modernity" actually began, modernism has a specific beginning, tracing back to the early twentieth century when writers like Virginia Woolf and James Joyce began experimenting with forms. Modernism seems tied to aesthetics. In Janet Wolff's study on women and modernity, 
she calls modernism "the formal innovations in artistic language" (57). These innovations are the results of artists trying to find authentic methods at representing their experiences with modernity. In contrast, definitions of modernity focus on the subjects that show up. The emphasis is on "the specific experiences of the modern age and the modern city" (Wolff 57). The characteristics that Baudelaire attributed to the flâneur were men's interests based on their experiences. Baudelaire popularizes the image of the ideal artist: a lover of crowds (which requires an access into public spaces) and an incognito (which requires the power of a detached gaze). Both of these Baudelairedefined qualities are guaranteed on the basis of his sex; they are not guarantees for women. What these female writers seek to find are narratives that represent the female experiences.

Rita Felski, similar to Wolff and Pollock, argues that in order to have a holistic understanding of women's interactions with modernity, we need to begin by looking at how men and women perceive their relationships with modernity, how they understood their presences during their times of change. Contesting other scholars' views concerning the placement of women in the discussion of modernity, Felski believes that the problem lies with modernity being defined so extensively within the public realm--a world dominated by masculine interests and ideas. While male writers focus on the ability to be anonymous in the crowd, the "fleeting, impersonal" encounters with strangers on the streets, and the "unmolested strolling and observations," (Pollock 58) these elements might not have been the concerns for women writers. What women writers chose as 
examples of their experiences with modernity would most likely be different from what the male writers chose.

Ogborn's study of spaces of modernity, like Pollock's for the field of art history, affords us one way of looking at how modernity is portrayed in literary texts, and even more crucial to this study, it affords us an approach to study women's interactions with modernity. We can re-read women's representations and interactions with certain spaces (bounded or otherwise) to understand their experiences with modernity. Or as I suggest, we can use space as the starting point to understand modernity. I contend that space is an important venue to study modernity and subsequently to locate the flâneuse. Seeing the locations of where she frequents and the locations she chooses to focus on in her works would help us to understand how she defines herself in relations to the 'modern' changes of her world. Yet looking at early modern texts of the seventeenth and eighteenth century, which scholarship of the flâneuse have largely ignored, it is useful to consider how class issues, gender roles and in conjunction with that, sexuality, interact with space to determine women's experiences with modernity. 


\section{Chapter Two: Isabella Whitney-the First Flâneuse}

Taking into consideration Toulmin's premise that the Renaissance marked a modernity in the literary traditions of its time, Early Modern England, from its economic, social, and literary vantage has all the makings of a city welcoming the birth of modernity, and thus can serve as an appropriate beginning point to look for our flâneuse. By the mid-sixteenth century, London had already experienced tremendous growth. It moved from being the seventh or eighth largest European urban city in 1550, to the third largest by 1600, and second largest after Paris by 1650 (Porter 66). The reason for London's vast growth in population was due to high immigration and periodic high rates of mortality (Sheppard 127). Although the metropolis experienced low population growth due to late marriages, it was able to offset this by the mass migration of individuals from areas around the country where there was an excess of births over deaths (Sheppard 128). The migrants, an average of 7,000 a year, consisted of the "rootless poor" who were attracted to London by the high wages offered; the apprentices from around the country came in search of the advancement the city infamously promised; the landless class from the countryside came because the traditional rural life was no longer sustainable (Sheppard 128). Rasmussen considers the sixteenth century to be the turning point for London (51). England has ceased to be the exporter of raw wool to nearby countries and monopolized the production of cloth. The industry's center was London, the headquarters for many companies created to ensure smooth trading with nearby countries. London, by the period of the Stuarts, had garnered independence separate from the power of the crown. To illustrate London's unspoken power over the crown, 
Rasmussen writes: "It was London who paved the way for Cromwell's rule. He kept power because his policy was favourable to the commerce of London. Again, it was London that made Charles II king, and it was with the help of London that William of Orange came to the throne" (59). While these strong claims attest to the political power that this city held, its economic power needed no convincing. London was becoming a city in flux. Jean Howard, in Theater of a City, writes that with the city expanding so rapidly, it was becoming more difficult to "know" its various forms. Howard writes: “"know' not just in the sense of having familiarity with the streets and buildings of various districts but also in the sense of having a conceptual image of the activities imagined to characterize these new areas and of the kinds of people who inhabited them" (5). He argues that dramatists present certain London places on stage and in doing so, they are describing and reimagining the new as well as the old characteristics of the city. This same attempt to understand the city is present whenever a society encounters changes. Writers in the sixteenth century were themselves trying to understand the drastic changes the city was experiencing, and one such writer was Isabella Whitney, the first woman in England who was able to publish a volume of poetry. Whitney published A Sweet Nosegay or Pleasant Posy: Containing a Hundred and Ten Philosophical Flowers in 1573. The last poem in the collection is titled "Will and Testament," perhaps her most well-known and frequent anthologized piece of writing. A satirical piece in nature, the 365-line poem features as its narrator an impoverished woman who has lost her position as a servant in a household and is not only mired in poverty but also dying. 
She takes to writing a will, yet finding she has no possessions of her own to give away, she gives to London items that the city already possesses.

The beginning of the poem answers the question of access - how our narrator moves around the city — using an interesting dynamic of an ending relationship. In the poem, we have a female narrator who takes us on a walk around the city. The opening of the poem describes a relationship in which the narrator is the spurred and rejected lover. The other partner has been cruel, and the city is described as a calculating, thrifty lover. The description focuses on the economical aspects of the relationship: "thou never wouldst credit give / to board me for a year, / nor with apparel me relieve / except thou payed were" (Whitney 21-24). This introduction sets up the whole tone of the poem. It asks readers to look at this relationship through this particular lens. Portraying the city as a lover allows the narrator to shape an intimacy with the city, an intimacy that explains her descriptions and how she gains entrance to these public spaces regardless of her gender.

In "Will and Testament," through the numerous references to London's power as a rising metropolis and a center for trade and commerce, Whitney presents a narrator who exemplifies the first telling characteristic of a flâneuse - that of observation. The poem can be thematically divided into two sections: the first highlights the glamour of the rising metropolis while the second part offers warnings to those who stay too long and are not careful. The narrator begins by presenting an aerial view of London; the starting point of her verse: St. Paul's. Since its construction, the cathedral has served as a centerpiece of London's skyline. Moving from St. Paul's, Whitney offers a close-up 
view of city life. What makes her verse exemplary in its contents is that Whitney narrows in on the working class and issues related to that class. The everyday professions of bakers, brewers, mercers, goldsmiths, and bookbinders are spoken with a sensitivity of one who understands the attractions of city life as well as its struggles.

The references to the world of commerce come in two forms: the professions cited and the physical landmarks that Whitney chooses as the recipients of her bequests. In her depictions, we get a glimpse of how London was changing while its population was trying to adapt. The myriads of professions of the working class are a testament to the high demands the city had for things from food to entertainment. After introducing St. Paul's, Whitney offers us a tour of the surrounding areas. She introduces butchers, brewers, bakers, mercers, goldsmiths — professions that rose up due to the city's high demands for food and commercial products. Those mentioned by Whitney were guild professions. Around the Tudor period, membership requirement for youths to enter guilds were less restrictive, thus from then until the mid sixteenth century, three quarters of London's adult male population belonged to guilds (Porter 49). Guild membership was the "escalator of advancement" (Porter 49). For the newcomers to the growing metropolis, it held promises of freedom and of future financial gains. By 1500, the "Twelve Great"-- the name referring to the twelve most reputable guilds--were the Mercers, Grocers, Drapers, Haberdashers, Fishmongers, Goldsmiths, Skinners, Merchant Taylors, Salters, Ironmongers, Vintners, and Cloth-workers (Porter 49). These professions became a draw for the mass migration of people into the capital. 
In addition to the references to the professions of the working class, Whitney's descriptions of popular streets and markets in London further extends her painting of the capital, and these descriptions reveal the autobiographical details of our poet. The narrator mentions rich silk and jewels in Cheapside Market. In Stocks, one can find knickknacks from combs to glass. Cheapside and Stocks were two of the four great food markets that straddled the streets from Newgate to Aldgate (Porter 48). Cheapside, by 1300, was already occupied by at least 400 shops (Sheppard 110). East from St. Paul's, this market was the retail center of the capital, providing the city with various manufactured goods. These small shops, 6 feet by 10 feet in length, along with warehouses were lined up both sides of the narrow streets. Howard calls Whitney a "guide" to London (69). Her descriptions stay within the Southwest quadrants of the old walled city (Howard 68). Her walk around London details where people can purchase food, clothing, and items of luxury. Yet the power to purchase is for those with money. For those who make up the population of the poor, Whitney focuses on a more somber aspect: prisons. What supplements her ability to walk with such freedom is her class. The poem reveals that the narrator is from the working class. Born in London, her parents live in Smithfield, an area known for its fish market. Critics argue that the poem is somewhat autobiographical. Little is known about Whitney's birth and death. Yet her knowledge of household duties suggests that she might have been a servant in a household during her lifetime (Gregerson 502). Her understanding of commercial London could have stemmed from the many trips she made running errands for her employer. 
While the first section of the poem features how the various guilds were providing food, clothing, weapons, and jewels to the masses, in the latter part of the poem, when she focuses on prisons, the voice of the narrator as an observer of social ills becomes more poignant. As a flâneuse, the ability to engage in flânerie, the act of walking, is a freedom that does not come easily. The streets are a contested space for these female characters. When female characters take to the streets, there is an inherent social critique in tandem with their walk that demands their engagement. In Whitney's poem, the narrator not only showcases the commercial nature of London, but she also references debtors' prisons like the Counter and Ludgate. These references are criticisms of what was wrong with the growing metropolis. Though the city presents itself as a place of abundant opportunities, the reality is that employment was unsteady. When she introduces Ludgate, she introduces us to a system of debt and credit that remains problematic into the next century.

What makes you standers by to smile, and laugh so in your sleeve:

I think it is because that I to Ludgate nothing give. $\cdots$

When days of payment did approach, I thither mean to flee, To shroud myself amongst the rest that choose to die in debt 


\section{Rather than any creditor}

should money from them get. (Whitney 211-228)

Rather than choosing to borrow money from a creditor, she chooses death. Howard argues that Whitney's "Will and Testament" is a monumental piece of work because of its representation of prisons. The poem reveals how changes in the city encouraged a more robust consumer market, yet concurrently, it encouraged a debt system and the potential of imprisonment as a result of accruing debt (Howard 71). Whitney's narrator draws attention to not only the glamour of the city but also its less favorable characteristics. Serving as a commentator makes the flâneuse different from her male counterpart, who practices indifference.

As the first example of a flâneuse, the narrator of Whitney's poem is an observer of modernity. The aspects of modernity the narrator focuses on involve both commercial and geographical changes. While this first example of the flâneuse presents an exciting look at women's interactions with the city landscape, this piece of work is missing one characteristic of modernity: the crowd. This characteristic is an important development in the flâneuse since the crowd is synonymous with the development of a city and a consumer society. In Whitney's poem, there is no discussion of the crowd, and more importantly, our narrator's interactions with the crowd. 


\section{Chapter Three: Costumes and the Dangers of Walking in The Roaring Girl and The}

\section{Rover}

The previous chapter focuses on how Whitney's narrator, as a flâneuse, is able to make aspects of the metropolis visible to her readers. She presents how inequalities between the poor and the rich were becoming more apparent. In this chapter, I focus on the emergence of a crowd and its potential as a moving force of change and danger to our flâneuse. In this second stage, she changes from being just an observer and recorder of societal changes to a woman who interacts intimately with the crowd.

The Roaring Girl (ca.1607-1610) by Thomas Dekker and Thomas Middleton is part of the city comedy tradition of the Jacobean era that presents London as an everchanging spectacle. City comedies refer to plays written sometime between 1598 and 1618 about London or cities that serve as representations of London (Howard 19). These plays focus on heroes who are the everyday citizens; instead of showcasing monuments and historical landmarks, the city's lesser glamorous sites (shops, taverns, prisons) are staged repeatedly (Howard 21). James Knowles writes that The Roaring Girl "develops the City as a spectacle, full of dangers, pleasures, monsters, and prodigies" (xxxviii). The idea of the city as a spectacle suggests that there is something there to watch and observe. Such a locale welcomes the presence of our flâneuse, one like the leading lady of The Roaring Girl.

At the center of The Roaring Girl are Moll Cutpurse and her world of associates — shopkeepers, artisans, and thieves. The play's autobiographical nature carries on Whitney's theme of presenting the working class and presents Moll on the 
streets of London, among shop stalls. Moll, our Roaring Girl, is a character Dekker and Middleton crafted for the stage from the real life figure of Mary Frith. A daughter of a middle-class shoemaker, Mary Frith was born between 1584 and 1589 (McManus 216). Her birth year varies from source to source. An autobiography, supposedly written by Frith herself titled "The Life and Death of Moll Cutpurse," was published in 1662. In it, Frith discusses her dissatisfaction with being a woman and being in service to someone else. So she made the decision to wear men's clothing, "fence" stolen goods, and visit taverns.

The Prologue opens by describing different groups of "roaring girls," divided by what time of day she takes to the streets. The term follows the term "roaring boys" a word that was ubiquitous during the late Elizabeth's reign, referring to a type of boisterous masculinity (Knowles 391). The Prologue introduces first the suburb-roarers, of which there are two types: "One is she / That roars at midnight in deep tavern bowls, / That beats the watch, and constables controls" (Dekker and Middleton 16-18). The second type: “Another roars i’th' day-time, swears, stabs, gives braves, / Yet sells her soul of the lust of fools and slaves" (Dekker and Middleton 19-20). With lax authority from the City's magistrates, the suburbs were places known for a high number of criminal activities (Knowles 391). Located just outside the city's walls, when city-gates closed during the night, the suburbs, left without legal authority, were home to brothels and much of what is considered the underworld of a growing metropolis (Mulholland 77). The term "roars" is significant because it denotes both the action of "roaring" and subsequently the characteristics of the roarers. The action of roaring is a link to one's 
occupation. Thus the first type of suburb roarers enters her "work" late into the night, and her occupation involves escaping and avoiding guards and constables. One can denote that her work surroundings are the tavern and brothel types. The descriptions of suburb roarers during the day reference the pickpocket, con-artist types of street workers. What we get in these two types of suburb dwellers are sketches of the occupations that some women might hold in a growing metropolis.

Moving from the streets, the Prologue continues to describe roarers who occupy the domestic setting and ends with the category that describes our heroine. "Then there's besides, / A civil, City-roaring girl, whose pride, / Feasting, and riding, shakes her husband's state, / and leaves him roaring through an iron grate" (Dekker and Middleton. Pro. 21-24). The Prologue depicts a wife who spends her husband's fortunes and ultimately this leaves him in prison. At the time, debtor's prisons were places of slow horror and no return. One more type of roarers remains: a "loftier" one. "None of these roaring girls is ours — she flies / With wings more lofty" (Dekker and Middleton. Pro. 2526). It is this loftier type of roaring girl that the play will consider. This introduction to roaring girls echoes Dana Brand's research on the Theophrastian character sketches. These sketches, according to Brand, were one of the stages in the development of the flâneur. They present the idea that one can assume someone's status based on appearance. It is this ability that goes in tandem with the flâneur's activity of observing strangers on the streets. The flâneur recognizes and categorizes those that pass him by using these sketches. What Brand continues to show was that these sketches were limiting, and this phase in the flâneur's development was short-lived. It was not always 
the case that certain occupations or people from a certain class would look and act a certain way. Mistaking the character and identity of people based on appearance or dress code shows up in this play and will be carried on in the texts of the later centuries as well.

What makes Moll a different flâneuse is her ability to utilize costumes to gain entrance into public spaces - places that are inaccessible to her gender. Moll shows up in public spaces and exudes confidence as equal to (if not better than her male counterparts) because of her hermaphroditic costume: half dress, half men's wear. In her first appearance, she strolls through the streets, dressed in a man's "frieze jerkin" and a woman's "safeguard"-clothes that adds to her androgynous character. It is a market scene, with three shops: an apothecary, feather, and sempster. The minute Moll enters this row of shops, there is much excitement and recognition from the shopkeepers. Women who dressed in men's clothing were an appalling concept in the sixteenth century, and the sentiment only intensified in the next century (Rose 369). What the act of dressing in men's clothing called attention to was the possible fragility of societal concept of gender roles and their moral character. Rose writes: "The fear seems to be that without rigidly assigned, gender-linked roles and behavior, legitimate, faithful erotic relations between the sexes will become impossible and the integrity of the family will consequently disintegrate" (374). Women who dressed in men's clothing disrupted the clear divisions of gender and gender-sanctified actions and roles. Moll's hermaphrodite outfit upsets the structure of class, sex, and power linked with gender-specific roles.

The other quality that makes Moll an example of a flâneuse is her exertion of independence outside those allowed for women and her refusal to follow what is 
expected of her gender. In the first scene with Moll, the appearance of a young fellow who wants to seek revenge on Moll presents the first opportunity in which Moll's boldness comes into play. She beats the fellow, and when Laxton comments that had the fight continued, he would have stepped in to help Moll, she retorts back: "Why do you speak this then? / Do you think I cannot ride a stone-horse unless one lead him by the snaffle" (Dekker and Middleton. 1. 3. 244-5). The reference of a stone-horse also means a man. Here, Moll asserts her authority and independence. Rather than accepting Laxton's offer, and in general a man's offer to help, Moll advocates for her own strength and ability to fight her own battles.

In her second meeting with Laxton, she uses the opportunity to criticize Laxton and his belief in judging women's social status based on mere appearances. In Act III, Moll meets with Laxton in the field, and he is caught by surprise when she demands a duel. Her purpose: to teach "his base thoughts manners" (Dekker and Middleton. 1. 5. 67). Moll criticizes his demeaning belief that just because a woman looks his way, it does not mean that she is to be conquered or wants to be conquered: "Thou'rt one of those / That thinks each woman thy fond flexible whore, / If she but cast a liberal eye upon thee, / Turn back her head, she's thine; or, amongst company, / By chance drink first to thee, then she's quite gone" (Dekker and Middleton. 1. 5. 67-71). Laxton makes the assumption that because a woman makes jokes and acts happy, it is a sign that she welcomes a man's advances. Promiscuity is directly tied with any response a woman gives. Moll in this scene points out the ridiculousness of such assumptions. Moll's contemporary society's obsessive belief in the direct correlation between "women's 
speech and their bodies, between free speaking and loose sexuality" are problematic and unfair (Miller 13).

Moll's aggressive independence, transgressing the proscribed, private roles for women, makes her into a kind of early modern flâneuse. In the same speech, she delivers what is perhaps the most gender-conscious soliloquy in the play:

In thee I defy all men, their worst hates

And their best flatteries, all their golden witchcrafts

With which they entangle the poor spirits of fools:

Distressed needle-women and tradefallen wives-

Fish that must need bite, or themselves be bitten-

Such hungry things as these may soon be took

With a worm fastened on a golden hook:

Those are the lecher's food, his prey. He watches

For quarrelling wedlocks and poor shifting sisters:

'Tis the best fish he takes. (Dekker and Middleton, I.v.87-96)

Her comments reference the role of prostitution in a growing metropolis and society's lack of understanding of women who had to commodify their bodies. These are poor spirits, who are naïve enough at time to fall for these men's lies. She points out that those who fall prey to prostitution were women who, though poor, were once virtuous. They were tradeswomen who earned their living through respectable means. Desperation, from hunger or poverty, turns them to this occupation. Jo Miller asserts that Moll's speech is aggressive, and that her statement makes her a dangerous character in her time 
period: "Moll's recognition of the economic deprivation of women, their total financial subjugation under the laws of patriarchy is what makes her such a dangerous character in her world" (Miller 13). In voicing her criticism of a system that continually perpetuates women's economic and social plight, Moll displays the second characteristic of a flâneuse. She goes beyond that of observation and makes visible society's problems. Though on stage the message might be downplayed by the jest and comedic factors, once the play ends, the image of a woman dressed in men's clothing asking to be treated as an equal will resonate with the audience. Moll makes observations of the misgivings of her society, and she becomes the voice that brings attention to their plight.

Another issue that she tackles is marriage. Moll's take on marriage, as she declared to Sebastian when he first courted her, is that it means the loss of her freedom: "I have the head now of myself, and am man / enough for a woman: marriage is but a chopping and changing, / where a maiden loses one head, and has a worse i'th'place" (Dekker and Middleton. 1. 4. 40-42). Her words point to the inequality that can occur in marriage. Even at the end of the play, she still declares that marriage is not for her. Only when honesty and truth are upheld in their entirety and rights are triumphed, only then will she marry:

When you shall hear

Gallants void from sergeants' fear, Honesty and truth unslandered, Woman manned but never pandered, Cheaters booted but not coached, 
Vessels older ere they're broached.

If my mind be then not varied,

Next day following, I'll be married. (Dekker and Middleton. 1. 11. 217-

24)

The conditions she sets that will lead to her marrying are next to impossible. She casts herself as an outsider, one who cannot join in with the conventions. The play ends with marriage; it is a "comedy" in that a happy marriage rights every wrong and things are back to the way they should be. Traditional institutions, marriage being the oldest, are celebrated, and Moll, stepping aside to deliver her soliloquy, comments favorably on the happy scene. The scholarly assessment of Moll is that in spite of her ideology, her refusal to marry, her dressing up in men's clothing, her speech/mannerism, at the end of the play, the play does not applaud her differences, and Moll does not encourage other women to follow in her example. Moll serves the institution of marriage by enabling the "proper" union of Mary Fitzallard and Sebastian. She even appears in the last act in a bridal gown and not men's attire.

The Rover by Alpha Behn, published in 1677 more than half a century after The Roaring Girl, continues with the second development of the flâneuse. This time, the focus shifts to women of the upper class. Behn portrays the characters of Florinda and Hellena as flâneuses who, using men's clothing and costumes along with the cover of carnival time, are able to stroll freely through the streets. Similar to the roaring girl (Moll), Hellena and Florinda also actively interact with the crowd. The flâneuse's ability to navigate the streets is essential to her development. Though anonymity is hard to 
achieve, the streets are a space that is open for her to engage in flânerie. In The Rover, we see examples of women who take to the streets to achieve freedom. Yet for some, flânerie comes more easily than for others. The play presents flâneuses who are both successful and unsuccessful in their navigation of the city streets. The reality of the unsuccessful attempts demonstrates historically the growing restrictions on women's presence outside of the home.

One of the themes from The Roaring Girl that gets carried to The Rover is that of the freedom that costumes allow to female protagonists. For Moll, cross-dressing allows her a sense of confidence that nothing else can afford. In her costumes, she assumes an identity that extends beyond her class and gender. For the female characters of The Rover, costumes allow them to experiment and grant them freedom from their oppressive brother and father and to roam and search for romantic exploits. Florinda and Hellena are young and inexperienced in love; uninhibited passion or love has been out of their reach. Through costumes and disguises, they roam the streets of Naples during Carnival time and pretend to be women experienced in sexual conquests.

The female characters take to the streets because of the stifling patriarchal authorities governing their lives. Hellena is preparing to enter a nunnery at the will of her father while her sister, Florinda, though in love with a young Englishman named Belville, is forced to marry an old, albeit rich suitor of her father's choosing. Hellena calls this arranged marriage a fate worse than her confinement in a nunnery. Both women in defiance of their fates declared words of escape and freedom. Florinda declares: "With indignation, and how near soever my father thinks I am to marrying that hated object, I 
shall let him see, I understand better what's due to my beauty, birth and fortune, and more to my soul, than to obey those unjust commands" (Behn. 1.1). For Florinda, it is about making a stand and asserting her independence to choose. While Florinda is trapped by her father's plans for an arranged marriage, Hellena's future confinement is the four walls of a cell and daily prayers. Convinced that this carnival is the last opportunity before a life of prayers and restrictions, she presses Florinda and her maids to take to the streets in costumes:

Callis: What, go in masquerade? 'twill be a fine farewell to the world I take itpray what would you do there?

Hellena: That which all the world does, as I am told, be as mad as the rest, and take all innocent freedom—sister, you'll go too, will you not? come prithee, be not sad. -We'll outwit twenty brothers, if you'll be ruled by me-come, put off this dull humour with your clothes, and assume one as gay, and as fantastic, as the dress my cousin Valeria and I have provided, and let's ramble. (Behn. 1.1) This ramble marks their first journey in costumes.

In the first walk, using the disguise of costumes and aided by Carnival atmosphere, the female characters assert independence. The streets of Naples are filled with Carnival goers. The crowd is mixed with men, in costumes playing music and dancing, and women dressing up as courtesans with "paper pinned to their breasts and holding baskets in their hands" (Behn. 1.2). In these women's appearances, the image of innocence and promiscuity is combined into one. Dressed as gypsies, Hellena and Florinda act the parts of romantically unattached women in search of their own suitors. 
In their ramble, they blur the lines between promiscuity and innocence. Many critics have argued that these women in costumes undermined the very patriarchal definition of whores and virgins. The costumes allow them to act bolder and experience a freedom in speech that their true identities as women of the upper class could not provide. The men in turn do not know what to make of these women.

Their varied encounters with Willmore and his entourage of fellow exiled cavaliers provide moments where our flâneuses take charge in the courtship process. Hellena, taking advantage of her costume, approaches Willmore the first time she meets him. She welcomes his advances and makes some of her own. True to her statement to Florinda before their walk about "trying out her fortune," she reveals to Willmore that she is destined to enter the convent, an admission that gives an expiration date to their amour. In this scene, what makes Hellena's character interesting is that she puts herself on equal footing with him. Where he is promiscuous, she, too, can be equally as scandalous. This first walk sets up the stage for the rest of the play. A group of young, lustful men encounter two young girls, Florinda and, Hellena, the more brazen sister of the two. The leader of the group, Willmore, is idealized because he is a rake. The scene is a long street. The women, in many ways, parade themselves in front of the men, asking for attention. Stephen Szilagyi, referring to the sisters and Angelica (a famous courtesan and love rival to Hellena) writes: "In fact, with all four women the distinction between whore and "virgin" is in some way blurred. Thus, Hellena and Florinda appear as "gipsies," or cross-gendered female rovers, in a crowd that includes both real and 
feigned courtesans (447). What follows then is a series of quick bantering filled with disguised motives and false promises.

On their second walk, Hellena admits to Florinda her insecurities, and we see a different woman than the one that stood in front of Willmore the evening before. In front of her sister and confidante, Hellena becomes a love-sick young girl, afraid of her lover's infidelity. Yet she is quick to defend her freedom to choose. To Florinda, she declares: "I don't intend every he that likes me shall have me, but he that I like" (Behn. 3. 1). Following their talk, Hellena spies Willmore approaching and decides to approach him once again. Dressed with her vizard, a mask used for disguise, she engages in banter on inconstancy between lovers. What is interesting about Hellena is that she does not claim to be a virtuous lady. Cunning, more daring than Florinda, Hellena goes about garnering Willmore's interest by pointing out their similar traits. Most notably, she remarks that both can be inconstant in their affections.

What makes The Rover a different document showcasing the flâneuse is how it addresses the issue of upper class women and their ability to navigate the streets. Women who belong to the upper class utilize costumes and the mask of Carnival time to walk. Yet inherent in this activity, and even more linked to their class, is the possible danger. The Rover is the only text selection so far in which we see representations of the dangers of walking. Florinda in one her walks, is followed at first by Willmore and then her brother. In dressing up in costumes and taking to the streets in costumes, she becomes more susceptible to danger. Willmore is drawn to her costume and chases after her. Escaping to the streets thinking to use the winding roads as rescue, she instead seeks 
refuge in a house where she is almost assaulted by Blunt and Frederick. Both mistook her for a wanton woman, partly because of her different costumes and partly because she arrives at their place uninvited. Unlike the roaring girl (Moll), who gains not only agency but also freedom in her costumes, Florinda's costumes actually become a threat to her safety.

Hellena is the only character in the play who successfully navigates the blurred boundaries of the streets and the private, domestic space, and this in turn makes her a flâneuse. On the streets, while in costume, she gains freedom and is more bold and daring in her speech. She inverts the traditional courtship dynamic by being the one wooing Willmore. How she navigates the private spaces is through men's clothing. In one scene, she dresses up as a boy to instigate the breakup of Wilmore and Angellica.

Derek Hughes argues that Behn was interested in the different boundaries of space and that women in The Rover are always framed, surrounded by closed spaces, like that of the bedroom or a private garden (38). However, these framed spaces offer only the illusion of safety and power. When a character like Willmore, who represents the extreme version of patriarchal dominance, enters this space, the female character is in danger of losing her power, her virtue, or both. The first example that illustrates this is with Angellica. Her picture hangs from the balcony's window like a shop sign, attracting her customers. Inside her bedroom, she at first holds power over Willmore, setting the price of her "service" and making him submit to her will. Yet the longer he is there, the faster she loses power and becomes more trusting of his words (Hughes 39). In the second example with Florinda, she is in more danger in private spaces than when she is 
out on the streets. Florinda arranges a lovers' meeting with Belville in the garden of her home. She leaves the garden's gate unlocked and a drunken Willmore stumbles in instead of Belville. He automatically calls her a wench. Her availability in this space suggests her class and a pre-supposed occupation. What ensues is a near-rape, and had not Belville arrived on time, Florinda's virtue would have been lost. The significance of this scene is in the fact that this garden, an enclosed private space that belongs to Florinda and once represented safety and power, can be made unsafe by Willmore's presence. Hughes writes that male characters in The Rover break down doors and barriers easily (39), yet there are no boundaries that guard women from danger. She can be accosted on either side of a door (Hughes 39).

The Rover ends just as The Roaring Girl ends: in celebration of marriage and of conventions. Hellena, in spite of her knowledge of the nature of Willmore, still marries him. Stephen Szilagyi says it best when he labels the unions at the end of the play as masculine: "As the comedy ends with the usual pairing for marriage, Behn's emphasis on the equalities within these partnerships is unmistakable ... dominance is still gendered masculine ... also... [the] displays of freedom, of expanded choices, ... are enacted by characters purely to serve their own ends" (438). Behn's ending makes this play not, in any way, a feminist manifestation. Our "flâneuses" take walks, yet surrounded by patriarchal authorities, at the end of their walks, they return to their prison cells where things are relatively safer. Yet now, these cells have been encased with a fake layer of "freedom" and peppered with illusions of "free choice." 
In this second stage, as exemplified by the two female leads, Moll and Hellena, costumes allow the flâneuse to walk the streets and interact with the crowd. Their dependency on costumes, however, point to the fact that women can never be completely incognito on the streets. The danger inherent in flânerie is a growing concern for these women. In The Rover, when safety is in jeopardy, the flâneuse's role as a social critic becomes secondary. What this chapter traces is the growing difficulty for women of the middle class to be on the streets. In the next century, when the division between public and private spaces becomes even more defined, our flâneuses will encounter even more restrictions that limit their ability to practice flânerie. 


\section{Chapter Four: Thievery and Public Gardens in Moll Flanders and Evelina}

Up until this point, I have refrained from labeling the streets as a "public space." The female characters of The Roaring Girl and The Rover roam the streets, yet Florinda is the only example in which the division between private and public spaces is clearly marked, and she is the only example so far of how women's safety can come under attacked regardless of where they are. When we speak of the division between public and private spaces, we are speaking of the ideology of the separate spheres - an ideology that shaped every aspect of late eighteenth-century British society and culture. This ideology demarcated spaces according to gender. The determinants for this ideology were the Industrial Revolution and the development of the suburbs (Wolff 13). By the time of Defoe's Moll Flanders in early eighteenth century, this ideology was already in development. The many conduct books that were in circulation at the time were supplemental materials to this ideology. These books reiterated that men and women have different roles and thus should have access to different spaces. Women belong in the private spaces, the domestic scene of the home. Men belong to the public spaces, like that of the coffee houses, the Exchange, and the bars and brothels. Men were in charge of politics and economics, and by the nature of their professions, they needed places that allow them to step away. Public spaces like bars, brothels, cafes sprung up, and women were barred from entering. Though those of the middle class were governed more by this ideology than those of the working class, one thing was clear: this ideology made class an influential marker that governs not only gender roles but also identity creation. 
One quasi-public space that presents class in all its varied complexities is the realm of the pleasure gardens. Pleasure gardens were the popular form of entertainment of the eighteenth century. It offered the excitement of the open streets with its crowd, yet the element of danger is reduced, somewhat kept at a distance by the required fee for admission. Its popularity was in part due to the growing division between public and private spaces. People visited these fabricated spaces to explore a setting where there is a mixture of class.

In this chapter, I focus on two eighteenth century texts: Moll Flanders by Daniel Defoe and Evelina by Frances Burney. One text features a female character of the working class who wants to advance to the middle class while the other text features a woman of the upper class being mistaken at times for the working class. Moll Flanders presents a flâneuse who actively interacts with her environment and adopts the role of social commentator. What makes Moll a different type of flâneuse than her previous counterparts is the frequent self-reflections. Her numerous psychological musings on the motivation behind a walk are significant because they signify a flâneuse who is actively assessing her role and how she fits in with the rest of her environment. Moll utilizes society's norm of "looking your class" to her advantage as a thief. In Evelina, the flâneuse, our titled heroine, shows how the division between public space and private space was becoming more prevalent. Using the unique space of the pleasure gardens, where the general public can enter regardless of class, Evelina shows the limitation placed on women from entering certain public spaces. Juxtaposing Evelina's experiences at the pleasure gardens with that of Moll Flanders', we again see how space and clothing 
interact to form or disrupt a woman's identity. In both Moll Flanders and Evelina, the power of the crowd, an element synonymous with a metropolis' rising commercial power, is greatly emphasized. For Moll, the crowd aids her in her attempt to escape punishment for her crimes, while for Evelina, the crowd presents obstacles and proves once again, the dangers of walking the streets for women.

Daniel Defoe wrote Moll Flanders when he was in his early sixties. The novel's origins is said to be based on various women criminals of Defoe's time (Novak 374). Defoe made frequent visits to Newgate to meet with his publisher, and there he entered into conversation with these women. Two female criminals in particular were mentioned as the direct models for his novel: Moll King and Callico Sarah. The name for his heroine is speculated to have been taken from a combination of these two women's names. Published in 1722, the novel portrays a woman's life and her difficulties finding love, family, and wealth. Most notably, the novel offers the psychology of a woman on the path to a life of crime. When Moll contemplates the change in profession, it is with a heavy heart and reluctance. At nearly fifty years of age, a widow left friendless and with no source of income, she is tempted by a force she calls "the Devil." Scholars have noted nuances in having Moll as a narrator. They split between calling her narrative believable or calling her short of schizophrenic. Describing Moll as a narrator, Ian Bell writes that her psychology is very consistent. She presents her views and though she does not force her perceptions on readers, she remains consistent in the image of a seemingly innocent woman forced to commit these criminal acts. Bell writes that it is possible to view Moll as "consistently impulsive, cunning and volatile" (427). Bell believes that Moll's 
narrative is convincing whereas other critics have disagreed. Everett Zimmerman cites the preface of the novel, arguing that the preface reveals how the text has been altered by the editor (Defoe) to reflect a way of speaking that would have been more appealing to the readers at the time. Zimmerman labels Moll a narrator with a "limited point of view" (350) thus granting the editor opportunities to interject. Zimmerman calls her indecisive, confusing, and easily persuaded (365). He continues: "At the end of her criminal career, her whirlwind of disguises is both a cause and a symbol of her mental state. Madness lurks on the peripheries of her life" (364). Maximillian Novak agrees with Zimmerman's assessment that Moll's narrative oftentimes lacks cohesion. Readers should have doubts with Moll's narratives because she is undecided and uncertain about how to interpret her life's events (Novak 379). This uncertainty in Moll about how to interpret certain events explains the conversational tone she takes with her readers.

With Moll Flanders, Defoe presents a story with a narrator who is actively telling readers how to read a scene - a characteristic that separates Moll from her predecessors. She does this by evoking people's sympathy and directing them to prepare for what is to come. Her attempt at "setting up" a scene is naturally followed with Moll's interpretations. For instance, before her first walk around London in her new occupation, she prefaces it with "O let none read this part without seriously reflecting on the Circumstances of a desolate State, and how they would grapple with meer want of Friends and want of Bread ... Let 'em remember that a time of Distress is a time of dreadful Temptations" (Defoe 150-151). Hoping to gain sympathy and understanding from the readers, she tells them that what they are about to witness is a matter of 
necessity. Her first walk takes her to Leadenhall Market, a busy commercial street in London. Here at an apothecary shop, she becomes a thief and escapes to the streets. What we get is a narrator who is disoriented having just committed her first act of crime. She loses herself in the many corners and turns, and subsequently she not only loses her sense of guilt in this aimless wandering but her narration also makes readers lose their reproach of Moll's actions:

I cross'd the Street indeed, and went down the first turning I came to, and I think it was a Street that went thro' into Fenchurch-street, from then I cross'd and turn'd so many ways and turnings that I could never tell which way it was, nor where I went, for I felt not the Ground, I stept on, and the farther I was out of Danger, the faster I went, till tyr'd and out if Breath, I was forc'd to sit down on a little Bench at a Door, and then I began to recover, and found I was got into Thames-street near Billinsgate. (Defoe 152)

Her wandering takes her to the South side of the city. For Moll, the London streets are both scenes of her crimes and her means to escape.

Moll Flanders is the first flâneuse who utilizes the power of the "Crowd" to aid her in her escape. In one incident following this first walk, Moll visits St. James' Park and walks the Mall, a tree-lined promenade created at the beginning of Charles II's reign showcasing the many efforts at changing the look of London (Defoe 202). In this scene, Moll adopts the look of a respectable woman of the middle class to gain access to a young girl. She pretends to be a relative of a thirteen-year-old girl, and utilizing the commotion of the crowd who was excited to see the King's coach pass by, Moll steals the 
girl's gold watch. Making use of the distraction, Moll escapes: "I Took my leave of her in the very Crowd, and said to her, as if in haste, dear Lady Betty take care of your little Sister, and so the Crowd did, as it were Thrust me away from her, and that I was oblig'd unwillingly to take my leave" (Defoe 203). A flâneuse's presence on the streets is easily recognizable. With our previous examples, the women have employed costumes to disguise their true gender and class, and they achieve a temporary freedom. Moll in this scene utilizes both the power of costumes and of the crowd to her advantage. Moll recognizes that the crowd welcomes confusion and she uses commotion to become faceless in the crowd and escape. In the eighteenth century, the concept of the Crowd takes on a new meaning. With commercialization and the opening of more public spaces, the crowd as we have come to know it began to take shape: faceless, unapproachable, and indifferent. Moll Flanders is the first of this class of female strollers to make use of this newly formed entity in her new profession. While anonymity in the midst of a public scene is something a flâneur desires and can achieve easily because of his gender, it is a privilege that often eludes the flâneuse.

Repetition is another technique employed by Moll that is aimed at evoking sympathy from the readers; through repetition Moll re-interprets scenes for readers. The language of her guilt is repeated after each outing: "But with all my Sense of its being cruel and inhuman, I cou'd never find in my Heart to make any Restitution: The Reflection wore off, and I began quickly to forget the Circumstances that attended the taking them" (Defoe 163). Yet Moll dismisses the sentiment as soon as she places an appropriate label on it. Her guilt is sincere, yet the ensuing abandonment of her 
conscience is just as quick and real. This quick abandonment, in some way, is a necessity to survive in the profession. Having a guilty conscience all the time would only make it difficult for her to continue.

Moll Flanders' visit to a pleasure garden shows how easily a flâneuse's purpose of walking can be mistaken by men for something more promiscuous. On her visit to Bartholomew Fair, an event known for its scenes of debauchery, Moll meets a gentleman while walking in the "Cloisters." These were covered walks or arcades that were notorious as places to engage in otherwise less respectable behavior (Defoe 177). The encounter eventually leads to a trip to Knight's Bridge, a pleasure garden and turns into a visit to an inn. The gentleman mistook Moll for a prostitute because of where he encountered her. This act of mistaken identity becomes more common in literature as we approach the later centuries. The reasons are based on issues of class and what public spaces were suitable for which class. Moll's presence in the cloisters implies that she is of a lower class than what her attire would suggest. Moll, in so many words, lets readers know that she offered no resistance to what eventually took place. "At first I seem'd to be unwilling to go up, but after a few Words, I yielded to that too, being indeed wiling to see the End of it, and in Hopes to make something of it at last; as for the Bed, \&c. I was not much concern'd about that Part." (Defoe 177). It was curiosity that compelled Moll to return with this stranger to the inn. Yet the desire for some monetary contribution was still there as she reveals afterwards: "My Business was his Money, and what I could make of him" (Defoe 179). 
From this episode, Moll presents two opposing views of prostitution. On the coach ride back, after the gentleman falls asleep, Moll searches his pocket and takes whatever she finds there. After the stealing was done, Moll begins a rant of men who utilized the service of prostitutes. Blaming a weak constitution, a lustful body, and a stupidity in not being able to identify young women from older ones on the gentleman's part, Moll offers no apology for her action-ascribing the wrong to the audacity of such men to not know any better.

There is nothing so absurd, so surfeiting, so ridiculous as a Man heated by Wine in his Head, and a wicked Gust in his Inclination together; he is in the possession of two Devils at once, and can no more govern himself by his Reason than a Mill can Grind without Water; His Vice tramples upon all that was in him that had any good in it, if any such thing there was ... picking up a common Woman, without regard to what she is, or who she is; whether Sound or rotten ... prompted by his vicious corrupted Head he no more knows what he is doing, than this Wretch of mine knew when I pick'd his Pocket of his Watch and his Purse of Gold. (178) In the following section, Moll however offers her case as an exception. This gentleman that picked her up is in fact a respectable gentleman who succumbed to his base desire because of alcohol, yet he is not a bad man. She calls him "a Gentleman, a Man of Sense, and of fine Behaviour ... with an honest virtuous Wife, and innocent Children” (179). This need to distinguish that she was smart enough to pick a gentleman and not just some lustful man goes to show that during Moll's time, prostitution was still very much a taboo subject. Desperation made Moll steal, but in this episode, she became a kept mistress out 
of curiosity. She believes that prostitution is a matter of monetary necessity: "As I said above, they value not the Pleasure, they are rais'd by no Inclination to the Man, the passive Jade thinks of no Pleasure but the Money; and when he is as it were drunk in the Extasies of his wicked Pleasure, her Hands are in his Pockets searching for what she can find there" (Defoe 179). She refers to the prostitute as a "passive Jade" and never directly comments that her own action makes her one. Zimmerman writes that in this scene, Moll is full of contradictions. She questions and changes her perceptions of the man and the role she plays. He attributes her contradictory narrative to vanity - a need to validate her good nature (Zimmerman 367). He goes further to suggest that Defoe lost control of Moll's narratives here because of a failure to find a moral order that she can then follow (Zimmerman 369). In Moll's discussion of prostitution as an occupation, she focuses on money as the motivation, but she does not speak of the reason or the forced conditions that would make a woman take to the street in this role. Her refusal to even admit that her actions can be seen in that light, says more about her desire to be accepted by society and her society's conventional standards. Once again, she tells readers to read the scene differently, to see her in a different light. She cannot be a social critic because she is occupied with trying to frame a respectable identity of herself for her readers.

The reality of restriction placed on women, especially women of the middle class, is better exemplified when juxtaposed with the freedom a flâneur belonging to the same century had. One well known example is James Boswell. In the years from 1762 to 1763, James Boswell, a man of twenty-two, embarked on a trip to London. He kept a detailed journal of his activities in London, filling it with sketches and observations of 
city life. The journal presents the prime example of what we had hoped to have our flâneuse doing, yet the reality was that she was confined, more and more each day, to her domestic space. Boswell wrote of his visits to coffee houses, his many intellectual conversations at these established locales. He provided details of his many interludes with prostitutes. There were visits to pleasure gardens, to the theaters, and to parks. Boswell's journal highlights the attractions of London. He served the role of observer and engrossed his readers in the bustling city. Yet Boswell's discussion of flânerie, of what a flâneur is, reiterates once again concepts of freedom and anonymity:

London is undoubtedly a place where men and manners may be seen to the greatest advantage. The liberty and the whim that reigns there occasions a variety of perfect and curious characters. Then the immense crowd and hurry and bustle of business diversion, the great number of public spaces of entertainment, the noble churches and the superb buildings of different kinds, agitate, amuse, and elevate the mind. Besides, the satisfaction of pursuing whatever plan is most agreeable, without being known or looked at, is very great. Here a young man of curiosity and observation may have a sufficient fund of present entertainment, and may lay up ideas to employ his mind in age. (Pottle 68-69)

Boswell's image of a flâneur is male, a man of manners and with the economic means to gain access to public spaces. His purpose is to have the freedom to pursue his interests in total anonymity. Echoed in Boswell's entry is the belief that flânerie develops the intellectual power of a young man. What Boswell depicts is his definition of what a gentleman's education entails. In contrast, the education of a young gentlewoman was 
based on grooming her to become a lady of the household. The streets were inaccessible to her. Her education was one that was based on conduct books. It was an education that focused on distinctive ways a gentlewoman should act, dress, and talk and restricted her from many public spaces that once, though not as easily accessible, were still available for her fellow flâneuses of the lower classes to enter without social stigma.

Class makes for a key difference between the experiences of Moll Flanders and Evelina. Moll Flanders is a flâneuse of the working class. Though she aims to advance to the middle class and comes close many times to achieving this status, especially during her time as a landowner's wife in America, she remains a woman of the laboring classes. She has access to the streets and pleasure gardens of London. By the time we move to Evelina, we are no longer speaking of a flâneuse of the working class. Evelina is of mixed class status. Her relations include Madame Duval, "a waiting-girl at a tavern" (Burney 15) who married Evelina's grandfather, a man of gentile and even aristocratic connections. Madame Duval's other relations in London are her nephew, Mr. Branghton, and his three children. The Branghtons are of solid working class, Mr. Branghton having secured a solid income and status through his silver-smith shop on Snow Hill, an area with a somewhat unflattering reputation (Jones 423). Evelina's other companions in London are the gentille Mirvans. When Evelina is with them, she feels secure in her upper class status, but this sense of confidence is eroded in the company of the Branghtons and Madam Duval.

Evelina, published in 1778 by Frances Burney, is an epistolary novel that traces a young country girl's maturation in the city as she comes to find her identity. It features a 
flâneuse who serves the role of a guide. The heroine of Evelina is a visitor to London, much in the same light as Boswell. Evelina presents the city's attractions and also its less attractive features on a cautionary note. Evelina embodies a characteristic that her predecessors have: the power of observation. Her letters to her guardian detailing her activities in London are all observations a flâneuse makes of the world around her. Like Boswell, her education in society takes place at the various public attractions London offers. Through her very observant retelling of events and mishaps at various public spaces in London, Evelina presents the growing difficulties a flâneuse of the late eighteenth century might encounter carrying out her flânerie activities.

In Evelina's first few days in the city, she introduces us to the more civilized aspects of the city. In the company of the Mirvans, she walks the Mall at St. James' Park, goes shopping, visits the opera, attends a private ball, and becomes, in every aspect of the word, a respectable young lady out about town. In the introduction to the novel, Vivien Jones comments that Evelina's first few letters to her guardian are similar to the notes from a guidebook:

Her sketches, like notes from a guidebook for the discriminating tourist, provide a spirited alternative to Mr. Villar's purely moral guidance. Her frank assessments of the pleasures and shortcomings of the city's various attractions also add particularity and authenticity to the impersonal accounts offered by those contemporary tourist guides concerned mainly to celebrate the metropolis. (xvii) Jones notes that Evelina's guidebook has more charm than Ned Ward's The London Spy. Ward's text is a key work for scholars who study representations of London. The text, a 
mix of poetry and prose published in 1698, represents all aspects of the city-its filth, crimes, and vibrancy (Ogborn 106). The main character is a man from the country, new to London. Written partly as a guide of what not to do for readers who are new to the city, the text, at the same time, presents the city's flux as its main attraction. In a similar format, Evelina is written to inform as well as to educate. Filtered through the lens of this young girl, the text's many entries would have attracted young readers, those who were new to London and came to this city seeking the same excitement, the possibility of romance, and financial stability.

In Evelina, a central theme is what is considered appropriate conduct as it relates to one's class. Complications arise when the space frequented is one of dubious nature, like the pleasure gardens. Evelina's mishaps at public spaces are often the result of her not understanding fully the restrictions placed on class. She becomes the victim of mistaken identity, jeopardizing both her safety and reputation concurrently. Pleasures gardens in their nature during this period were a public space that is synonymous with the streets. As a public space accessible to the flâneuse regardless of class status, the pleasure gardens serve to address how flânerie was practiced in eighteenth-century London by women. Evelina enters this public space accompanied by her relatives and the Mirvans. Her companions, people of both the middle class and the gentry, provide an interesting tool to see how Vauxhall, representing the culture of pleasure gardens in general, made it almost impossible for women to engage in flânerie. More than any other public space, the pleasure gardens of the eighteenth century appealed to the general public and the growing consumer population who sought out the latest entertainment. 
Mollie Sands writes: "If you could pay the entrance money, were decently dressed and behaved with decorum, you would be admitted whatever your social status" (Sands 16). Though Sands wrote that statement referring to one pleasure garden in particular, Marylebone (also referred to as Marybone in some texts), the same sentiment can be expressed for all pleasure gardens during this century. By mid-eighteenth century, there were as many as sixty of these gardens available for public use (Sands 2). They were popular as evening resorts in which visitors often come for the fireworks, concerts, masquerades, and the facilities for eating and drinking (Wroth 5). Using the pleasure gardens as setting, Burney poses the question of how obvious class distinctions truly are. Can one's class always be distinguishable regardless of variables like space or clothing? Through Evelina's visits to these gardens, her interactions with the crowd and her accidental wanderings to the less reputable areas of these places, we see that class is tied directly to space just as much it is to one's dress. Because this is the case, the streets are no longer an option for women. Women's flânerie is increasingly done in confined spaces, and the pleasure gardens became one of the few spaces left for women to observe modernity in its variety.

Vauxhall had a universal popularity that surpassed its other rivals; in part, it was due to its ability to appeal to people of all classes. The public garden on the grounds of Vauxhall was there since the 1660s, but only under the new management of Jonathan Tyers in 1728 did it achieve its universal popularity. Tyers redesigned and reopened Vauxhall in 1732 with new forms of entertainment and it became London's most popular summer resort (Ogborn 120). It offered evening concerts, lighted walks, dinners, and 
fireworks and boasted of no class distinction. Ogborn, in arguing that the pleasure gardens were spaces of modernity, writes that Vauxhall, in particularly, was notable as a "site of cultural production" (118). This space showcased new artistic genres and new forms of entertainment. At the core of this space is a consumer society:

What was produced at such sites was produced for the market. Vauxhall's cultural geography was part of the eighteenth century's 'consumer revolution.' What was consumed was consumed in part because it was fashionable and for sale. It is this link between commodification and fashion that renders Vauxhall a space of modernity (Ogborn 119).

Vauxhall, in comparison with similar public gardens like Ranelagh and Marylebone, was more notorious for its unscrupulous characters. A contemporary ballad anonymously published sometime after 1790 about Vauxhall describes those who frequented Vauxhall:

See the motley crew advance,

Led by Folly in the dance, English, Irish, Spanish, Gaul,

Drive like mad to dear Vauxhall

Blust'ring soldiers with their trulls, Some with oars and some in sculls,

Butchers' wives from greasy stall

Crowd in shoals to see Vauxhall 
Deans and parsons leave their shrine,

How their gills and noses shine,

Deaf to fair religion's call

They pick up lasses at Vauxhall.

Courtiers, patriots, punks in rows,

Minsters, rogues, and plenipos,

Lawyers from Westminster Hall,

Join their issues at Vauxhall. (Cited in Southworth 113)

The poem echoes closely sketches of the city written by the earlier urban writers. The narrator offers his observations, telling readers what to seek out and who to avoid. The poem illustrates the mixed crowd but also the loose morals associated with these visitors. Butcher's wives leave their stalls to visit Vauxhall. Deans and parsons, people often associated with a high moral code, abandon their virtues and religion to chase after girls at Vauxhall.

Evelina's episodes at Vauxhall illustrates that one's class will come under scrutiny if the public space does not complement it. James Southworth wrote this about Vauxhall: "Class distinctions were forgotten when there was no need for them to be remembered, and flirtations were an accepted part of the evening's entertainment. Young bloods strolled about scrutinizing and staring the ladies out of countenance" (119). There was no need to remember class distinctions because the atmosphere had no restrictions 
and welcomed entertainment of a pleasurable nature. Where one could find these young bloods carrying out their act of gallantry was in the dark walks. These walks on the darker part of the gardens became notorious as the site where sexual encounters happened, both solicited and unsolicited (Jones 441). When the Branghton sisters recommend a visit to the dark walks of Vauxhall and Evelina voices her dislike, they, like their brother, make a sarcastic comment about Evelina's timidity. She follows them into the dark walks by compulsion and is accosted by parties of men who mistake her for a prostitute. One of the men calls her "the prettiest little actress" (Burney 198) he has seen. Actresses in the eighteenth century still had a notorious reputation. Because the nature of their occupation goes against the ideals of feminine propriety, their status was often seen along the line of prostitution (Nachumi 134). Sir Willoughby, too, questions Evelina's character. He comes to her rescue, and instead of leading her to safety, he becomes bolder-grasping her hands, professing his love, and subsequently leads her to an even darker alley. He, like those men before him, assumes that Evelina must have some agenda for being in the dark walks, and he takes more liberty because of this assumption. When Evelina reproaches him for his behavior by calling it insolence, he expresses his confusion: “ 'By Heaven,' cried he with warmth, 'you distract me,--why, tell me,--why do I see you here?-Is this a place for Miss Anville? - these dark walks! - no party! — no companion!- -by all that's good, I can scarce believe my senses!' " ( Burney199). He, like her previous assailants, believes that she wants to be solicited otherwise she would not be there. 
This scene portrays a scenario that highlights a reality that women encounter as strollers. Like Moll Flanders' episode at Knight's Bridge, Evelina enters a space that automatically imposes a class identity on her regardless of how she acts or dresses. She becomes mistakenly associated by just being present in that space. The nature of the dark walks allowed this confusion in Evelina's class and status, yet had the dark walks been exchanged with city streets, the same case of mistaken identities could have occurred. The flâneuse cannot be expected to roam without encountering some sort of danger. Evelina, serving as a guide to young ladies, offers these moments of near-assaults as a cautionary tale.

Ogborn argues that Vauxhall creates a culture of the spectator, with women as the object watched. Using the case of a Mrs. Hartley, a married actress who was gawked at by three libertine characters, Ogborn writes of the changing nature of the gaze: "The eighteenth century may have seen the emergence of the modern ocular and sexual ideology of the male spectator and the female spectacle" (149). This was the century when the distinction of the male as the spectator and women as part of the spectacle became more common. The famous incident, called the "Vauxhall Affray," (Ogborn 118) mentioned a friend of Mrs. Hartley who took offense that these libertines asserted too much freedom in gazing at her. The incident called attention to the subject of the gaze. Because Mrs. Hartley was an actress, these three men reconstructed the Vauxhall gardens into a spectacled space like that of the theater stage and she, in turn, became the object of their gaze (Ogborn149). She became "a woman in public" (149), and the assumption was that a woman in public will attract attention, unwanted or wanted. 
Evelina's mishap at Vauxhall is an example of how her presence in the dark walks comes to signify that she is a public woman, available to unsolicited attention from men occupying the same public space as her. The incident also explains the men's quick label of Evelina as a clever actress. Of Vauxhall, Ogborn continues: "Vauxhall Gardens was made of spectacles ... Everyone was on stage ... It was the pleasure of looking at others that were stressed, particularly of men looking at women" (151). This belief was problematic for women's flânerie. As "a woman in public," subject to the male's gaze, the flâneuse is watched, making it difficult for her to conduct any observation of her own. Evelina's visit to Marylebone is another instance where our heroine's identity is undermined and flânerie becomes a difficulty for her. Marylebone was another popular garden that rivaled Vauxhall in the eighteenth century. It was popular as a resort for visitors who wanted to be away from the city to get some fresh air. Marylebone, like Vauxhall, allows the intermixing of class and attracted a mixed crowd to its grounds. The newly prosperous middle classes and superior tradesmen from the neighborhood of Holborn (where Evelina resides with Madame Duval) came more often than the nobility from the South (Sands 16). In this incident at Marylebone, Evelina is judged not by where she visits, for there were no dark walks at Marylebone, but whom she is with. While watching the performance of Orpheus and Eurydice, an explosion occurs and starts a commotion. "There was such an explosion of fire, and so horrible a noise, that we all, as of one accord, jumpt hastily from the form, and ran away some paces.” (Burney 233). Evelina is a part of this escaping mass, and the crowd works against Evelina. She loses herself in the chaos: "For a moment or two, I neither knew nor considered whither I had 
run, but my recollection was soon awakened by a stranger's addressing me with, "Come along with me my dear, and I'll take care of you" (Burney 234). The mass has separated her from her party: "In vain, from side to side, I looked for some face I knew; I found myself in the midst of a crowd, yet without party, friend, or acquaintance" (Burney 234).

In Moll Flanders, the crowd's anonymity and strength in number aids Moll in her escape. For Evelina, the same characteristics prove disastrous. She seeks help and is accosted by men who can see her distress: "Every other moment, I was spoken to, by some bold and unfeeling man, to whom my distress, which, I think, must be very apparent, only furnished a pretence for impertinent witticisms, or free gallantry" (Burney 234). Similar to the incident at Vauxhall, Evelina once again finds herself in a predicament where her identity as gentlewoman, instead of aiding her actually hinders her escape. While trying to find her way back to her party, a young officer marches up to her and forcibly grasps her hand. She seeks help from two ladies who turn out, to her surprise, to be prostitutes: "I will not dwell upon a conversation, which soon, to my inexpressible horror, convinced me I had sought protection from insult, of those who were themselves most likely to offer it" (Burney 234). Her narrative about this encounter demonstrates her innocence in supposing a person's character is based on his or her appearance. When she realizes her mistake, these women have latched themselves onto her and refuse to leave her side. Her fear of being seen with them by someone she knows escalates when she sees Lord Orville in the crowd: "Never shall I forget what I felt at that instant: had I, indeed, been sunk to the guilty state, which such companions might lead him to suspect, I could scarce have had feelings more cruelly depressing” (Burney 235). 
He sees her presence with these women and wrongly misinterprets the signs. Her choice of words highlights a sense of female mentality that equates guilt with situations that might have been seen outside of the rules of propriety. It does not matter even if the situation is out of her control. What matters is that her reputation becomes questionable in these instances. This scene of mistaken identity illustrates the power of the crowd, and more importantly, the power of the public in identity construction. Evelina's experience at Marylebone demonstrates society's conventional outlook on prostitution and how a lady's company determines the public image of herself. Identity creation, as shown in the novel, is about appearance and can be easily undermined by public spaces and the power of the crowd. In a letter to Evelina, Mr. Villars cautions her: "This is not an age in which we may trust to appearances, and imprudence is much sooner regretted than repaired" (Burney 309). He echoes the reality of the age and the contradiction of being judged based on first impressions yet also how appearance can be misleading and cannot be used as a compass to judge a person's true character.

The flâneuse's role is to offer us a reading of the city, yet whenever her gender is apparent; she herself becomes the object of the gaze. Those around her begin to read or misread her presence in public. Costumes allow access to the public realm, yet they do not offer her complete freedom. By the time we get to Evelina, around the end of the eighteenth century, the idea of woman walking the streets was an abomination. The list of public spaces for women to explore was increasingly limited, and when there were any, they were, in some way, fabricated public spaces. 
Young women of the eighteenth century in many ways were increasingly forbidden to enter many spaces. On Evelina's visit to Bath later in the novel, she is accosted by a young libertine. Her companion, Mrs. Selwyn, attempting to dissuade him from pursuing Evelina further, retorts to his question about Evelina's whereabouts with this answer: "young ladies are no where" (Burney 275). This statement expresses appropriately the nature of eighteenth-century British women's access to public spaces. Young ladies are supposed to be at home - the only acceptable space reinforced by the ideology of the time. 


\section{Conclusion}

In the span of four chapters and a time frame of over two hundred years, we have witnessed the development and temporary stasis of women's flânerie in literature. The flâneuse makes her first appearance in Isabella Whitney's sixteenth-century poem "Will and Testament." As the first example, Whitney's narrator places emphasis on a key trait of a flâneuse, that of observation. London is presented with both microcosmic and macrocosmic qualities; all of its excitements and filth are laid bare. This first flâneuse also presents the second characteristic, that of criticism. Perhaps the most defining quality separating the flâneuse from her male counterpart is this quality of a critic. Since the freedom to walk is hard-earned, such an activity in itself is risky and thus demands a purpose beyond that of a casual stroll. The flâneuse on the streets is essentially a social critic.

From Whitney, we move forward to Thomas Dekker and Thomas Middleton's The Roaring Girl and Aphra Behn's The Rover. These two seventeenth century texts present the element of the crowd, an element of modernity whose presence will increasingly permeate society. The interaction with the crowd and the flâneuse's attempt at remaining incognito through the use of costumes and disguises are important aspects of her development in this century. These two texts also address the growing difficulty of flânerie and the dangers women might encounter walking in costumes. When these flâneuses' virtue or identity is at risk, the danger of walking becomes all the more pressing. Their role as social critic becomes secondary as they try to disentangle 
themselves from a dangerous situation. Though our study of the development of the flâneuse from the sixteenth to eighteenth centuries has been an attempt to present women who are more critical and observant of her urban landscape, especially the power of the crowd, what this study has shed light on is the slow disappearance of her presence on the streets. What we see is the exact opposite of gradual development; the flâneuse, especially those of the leisure class, slowly disappears from public spaces. The object of a flâneuse is to engage in flânerie. The early modern periods, the sixteenth and seventeenth centuries, saw a more socially welcoming setting for such a free-spirited female walker of all classes. When we get to the eighteenth century as exemplified through the last two texts of this study: Moll Flanders and Evelina, class became more distinguishable and the freedom to walk became limited. In public spaces that appeal to the growing commercialization of society and welcome the idea of the spectacle like that of the pleasure gardens, both Evelina and Moll Flanders encountered blurry lines of being an observer and being the ones observed. What explains the growing restriction placed on women to walk is the prominence of the ideology of the separate spheres. What we have were women being more confined to their private spaces - quintessentially the space of the home. Public spaces that were accessible by women became a narrowed list of spaces in which often times they cannot enter without chaperons. Not only was the flâneuse's freedom to walk taken away from her, her power to be an observer became more difficult to exert, and in conjunction with that her power to serve as a critic. The early examples of the flâneuse thus remain as remnants of a once-possible freedom. When the revolution for women to possess rights in politics, economics, and society 
exploded in the twenieth century, the flâneuse re-emerges in literature and resumes her walk. 


\section{Works Cited}

Baudelaire, Charles. "The Painter of Modern Life." The Painter of Modern Life and Other Essays. Trans. \& ed. Jonathan Essays. London: Phaidon, 1964. Print.

---. “To a Passer-by.” The Flowers of Evil. Trans. William Aggeler. California: Academy Library Guild, 1954. Print.

Behn, Aphra. Oroonoko, The Rover and Other Works. Ed. Janet Todd. London: Penguin, 1992. Print.

Bell, Ian A. "Moll Flanders, Crime and Comfort.” Moll Flanders. By Daniel Defoe. Ed. Albert J. Rivero. New York: Norton, 2004. 403-436. Print.

Brand, Dana. The Spectator and the City in Nineteenth-Century. Cambridge: Cambridge UP, 1991. Print.

Burney, Francis. Evelina or the History of a Young Lady's Entrance into the World. Ed. Edward A. Bloom. Oxford: Oxford UP, 2002. Print.

Clark, T. J. The Painting of Modern Life: Paris in the Art of Manet and His Followers. Revised edition. Princeton: Princeton UP, 1999. Print.

Defoe, Daniel. Moll Flanders. Ed. Albert J. Rivero. New York: Norton, 2004. Print.

Dekker, Thomas and Thomas Middleton. The Roaring Girl. Ed. James Knowles. Oxford: Oxford UP, 2008. Print.

Friedberg, Anne. "Les Flaneurs du Mal(1): Cinema and the Postmodern Condition." PMLA 106 (1991): 419-431. JSTOR. Web. 17. Oct. 2009. 
Gregerson, Linda. "Whitney, Isabella: c. mid-sixteenth century.” Poetry 187 (2006): 502504. EBSCOHost. Web. 10. June. 2011.

Howard, Jean E. Theater of a City: The Places of London Comedy, 1598-1642. Philadelphia: U of Pennsylvania P., 2007. Print.

Hughes, Derek. "Behn, Women, and Society." The Cambridge Companion to Aphra Behn. Ed. Derek Hughes and Janet Todd. Cambridge: Cambridge UP, 2004. Print. Jones, Vivian. "Introduction and Notes." Evelina or the History of a Young Lady's Entrance into the World. By Francis Burney. Ed. Edward A. Bloom. Oxford: Oxford UP, 2002. Print.

Knowles, James. "Introduction.” The Roaring Girl and Other City Comedies. Ed. James Knowles. Oxford: Oxford UP, 2008. Print.

McManus , Clare. "The Roaring Girl and the London Underworld." Early Modern English Drama: A Critical Companion. Ed. by Garrett A. Sullivan, Jr., Patrick Cheney, Andrew Hadfield. New York, Oxford UP, 2006. 213-224. Print. Miller, Jo. E. "Women and the Market in The Roaring Girl." Renaissance and Reformation 26 (1990): 11-23. Journal Publishing Services. Web. 18. Nov. 2010 Mulholland, P.A. "The Date of the Roaring Girl." The Review of English Studies 28 (1977): 18-31. JSTOR. Web. 16. Nov. 2010.

Nachumi, Nora. Acting Like a Lady: British Women Novelists and the EighteenthCentury Theater. Brooklyn: AMS Press, 2008. Print. 
Novak, Maximillian E. “ 'Unweary'd Traveler’ and 'Indifferent Monitor’: Openness and Complexity in Moll Flanders." Moll Flanders. By Daniel Defoe. Ed. Albert J. Rivero. New York: Norton, 2004. 349-368. Print.

Ogborn, Miles. Spaces of Modernity: London's Geographies, 1680-1780. New York: Guilford P, 1998. Print.

Pollock, Griselda. Vision and Difference: Femininity, Feminism, and Histories of Art. London: Routledge, 1988. Print.

Porter, Roy. London: a Social History. Cambridge: Harvard UP, 1990. Print.

Pottle, Frederick A. Boswell's London Journal, 1762-1763. 2nd edition. New Haven and London: Yale UP, 2004. Print.

Rasmussen, Steen Eiler. London, the Unique City. Cambridge: M.I.T. Press, 1948. Print. Rose, Mary Beth. "Women in Men's Clothing: Apparel and Social Stability in The Roaring Girl." English Literary Renaissance 14 (1984): 367-391. JSTOR. Web. 29. Dec. 2010.

Sands, Mollie. The Eighteenth-Century Pleasure Gardens of Marylebone 1737-1777. London: Society for Theatre Research, 1987. Print.

Sheppard, F.H.W. London: a History. Oxford: Oxford U.P., 1998. Print.

Southworth, James. Vauxhall Gardens: A Chapter in the Social History of England. New York: Columbia UP, 1941. Print.

Szilagyi, Stephen. “The Sexual Politics of Behn's Rover: After Patriarchy.” Studies in Philology 95 (1998): 435-455. JSTOR. Web. 21. Nov. 2010.

Tester, Keith. The Flaneur. London and New York: Routledge, 1994. Print. 
Toulmin, Stephen. Cosmopolis, the Hidden Agenda of Modernity. New York: The Free Press, 1990. Print.

Whitney, Isabella. "Will and Testament." Norton Anthology of Literature by Women. Ed. Gilbert, Sandra and Susan Gubar. New York: Norton, 2007. 68-76. Print.

Wolff, Janet. Feminine Sentences: Essays on Women and Culture. Berkeley, U of California P: 1990. Print.

Wroth, Warwick. The London Pleasure Gardens of the Eighteenth Century. London: Macmillian, 1896. Print.

Zimmerman, Everett. "Moll Flanders: Parodies of Respectability." Moll Flanders. By Daniel Defoe. Ed. Albert J. Rivero. New York: Norton, 2004. 337-348. Print. 